\title{
Preparation and Certification of Low Alloy Steel Reference Materials for Spectrometric Analysis
}

\author{
Adel B. Shehata ${ }^{1 *}$, Essam A. Kishar ${ }^{2}$, Doaa A. Ahmed ${ }^{2}$, Randa N. Yamani ${ }^{1}$ \\ 1 National Institute of Standards, Giza, Egypt, \\ ${ }_{2}$ Chemistry Department, Women's College for Arts, Science and Education, Ain Shams \\ University, Cairo,
}

\begin{abstract}
Matrix certified reference materials (CRMs) are versatile tools to support quality, correctness and credibility of measurement results. CRMs are used to provide the traceability of the measurement results to the SI unit. Seven low alloy steel certified reference materials were developed by the national institute of standards (NIS), Egypt. Homogeneity is studied using $\mathrm{X}$-ray fluorescence spectrometer (XRF) and optical emission spectrometer (OES). The characterization of RMs was performed using independent chemical methods as gravimetric methods, x-ray fluorescence spectrometry, optical emission spectrometry and atomic absorption spectrometry. Both the assigned values and their associated uncertainty were calculated by weighted mean approach after the statistical analysis of the results of measurements for the homogeneity of variances, equality of means, normality of data and outliers.
\end{abstract}

Keywords: Low alloy steel, Homogeneity, Reference materials, Traceability

\section{Introduction}

The quantities of steel products used for different industrial activities are enormous. The determination of chemical composition of steel products is important not only for the users but also for the manufacturing as well. The assessment of compliance of iron and steel products with their technical specifications is the main tool to judge their quality and to decide their industrial application. This assessment is done by measurements using different techniques such as X-ray fluorescence spectrometry (XRF), optical emission spectrometry (OES), atomic absorption spectrometry (AAS), and inductivity coupled plasma (ICP) [AlEshaikh M. A.-2011].

Corresponding authors: Adel B. Shehata, adelshehata63@yahoo.com 
Laboratories are required to use standard methods or validated methods if possible. Certified reference materials are versatile tools for internal validation studies. They play important role in the verification of the accuracy of analytical measured results. Certified reference materials are used to: 1) assure the quality of the resulting

measurements; 2) establish the traceability of internationally agreed standards to SI units, 3) calibration of the measuring instrument to establish the reliability of its readings and 4) estimate the uncertainty of the measurement process enabling the measurement results to be compared with other results, references, specifications or standards [Amigo J.M.-2011, Emons H.-2004]. P. Hoffmann et al examined seven steel samples as reference materials, which were produced by the research institute of CKD, Praha, CSFR (Czech Republic). They have been analyzed using atomic emission spectrometry with inductively coupled plasma (ICP-AES), atomic absorption spectrometry with flame and graphite furnace atomization (FAAS, GFAAS), differential pulse anodic stripping voltammetry (DPASV), X-ray fluorescence analysis with total reflection sample carrier (TXRF) and instrumental neutron activation analysis (INAA). The authors reported that over $90 \%$ of all results were in good agreement with the values determined by wet analytical methods. They, moreover, owed the deviations to systematical errors for special elements analyzed by distinct methods and to statistical errors for other elements which have low concentrations and were not homogeneously distributed in the given material [Hoffmann P.-1992].

In the present work, seven compositions of low alloy steel are prepared. The process of certification and characterization is described in the ISO Guide 35 [1992]. These reference materials are certified for mass fraction of carbon, silicon, phosphorus, sulphur, manganese, chromium, nickel, tin, molybdenum, copper, cobalt, aluminum, titanium and vanadium using independent analytical methods. Both the assigned values and their associated uncertainty are calculated by weighted mean approach according to Paule and Mandel approach [Schilier S.B. -1991] after the statistical evaluation of measured results for the homogeneity of variances, equality of means, normality of data and outliers.

\section{Materials and Methods}

\subsection{Raw materials and steel production}

Low carbon steel (carbon $\leq 0.1 \%$ ), ferrosilicon alloy (silicon content: $75 \%$ ), low carbon ferromanganese alloy (carbon $\leq 0.1 \%$ and manganese content: 80\%), pure metallic copper (99.50\%), pure nickel, (99.5\%), low carbon ferrochromium (carbon $\leq 0.1 \%$ and chromium 
content: 70\%) and Ferrovanadium alloy (vanadium content: $70 \%$ ) are used for the manufacture of low alloy steel. The production technology is developed to guarantee the maximum homogeneity of readability of the chemical composition of these alloys. Melting was conducted in a medium frequency electric induction furnace with $100 \mathrm{~kg}$ capacity at Central Metallurgical Research and Development Institute (CMRDI) experimental foundry, (E1 Tabeen-Egypt). Low carbon steel containing $\geq 0.1 \%$ carbon was charged at the top of the furnace crucible and remelted at certain temperatures. During the melting process, some elements such as nickel, chromium, manganese, vanadium, tungsten and other elements were added to improve properties of the produced steel. After the addition of the desired elements, the furnace temperature was raised to $1550{ }^{\circ} \mathrm{C}$ for 10 minutes. The hot liquid steel was transported into certain thermal crucibles with the addition of $0.02 \%$ of aluminum to remove the oxygen. Special designed water cooled copper molds were used for steel casting to ensure the maximum cooling rates, to minimize the segregation of the alloying elements and to maximize the homogeneity of the produced steel.

\subsection{Chemicals and reagents for sample digestion}

Nitric acid, 69\% was purchased from Analar, England. Hydrochloric acid, 37\% and hydrofluoric acid, 40\% were obtained from Merck, Germany. Lanthanum chloride, 99.99\% and cesium chloride, 99.9\% were obtained from Alfa Aesar, Germany. Hydrogen peroxide $30 \%$ and ammonium persulphate were purchased from Elnasr Co., Egypt.

\subsection{Analytical instruments}

X-ray fluorescence spectrometer (XRF), Axios, Panalytical, Elmelo, the Netherlands, with Rhodium target, $\mathrm{V}=60 \mathrm{kV}$ and $\mathrm{A}=160 \mathrm{~mA}$ is used for the quantitative analysis and homogeneity study. The atomic absorption spectrometer (AAS) (ZEEnit 700, Analytik Jena, Germany) used for quantitative analysis was equipped with a hollow cathode of the element operated at a current recommended by the lamp and instrument manufacturer. An automatic

deuterium background-correction was used for flame atomizer measurement. Microwave digestion instrument, TOPwave Analytic Jena, Germany, was used for sample preparation. Optical emission spectrometer (OES), Analytical Instrument, Thermo Electron, USA, is used for the quantitative analysis as well. Combustion cell, Leco, U.S.A. was used for direct analysis of carbon in oxygen atmosphere.

\subsection{Sample preparation for atomic absorption spectrometer (AAS)}




\subsubsection{Wet preparation}

Half gram of sample is weighed and transferred into $100 \mathrm{~mL}$ volumetric flask. $25 \mathrm{~mL}$ of $3 \mathrm{~N}$ sulphuric acid are added and then heated until sample was completely dissolved then $10 \mathrm{~mL}$ of $12 \%$ ammonium persulfate solution are added. The sample is boiled vigorously until a clear solution is obtained. It is left to cool then diluted to the specified volume with deionized water [Perkin Elmer publication-1996].

\subsubsection{Microwave digestion preparation}

Two hundred $\mathrm{mg}$ of the sample are weighed into the digestion vessel. $3 \mathrm{~mL}$ of $\mathrm{HNO}_{3}, 3 \mathrm{~mL}$ of $\mathrm{HCl}$ and $3 \mathrm{~mL}$ of $\mathrm{HF}$ are added. The mixture is stirred carefully and the sample is left for 10 minutes before closing the microwave vessel [Perkin Elmer publication-1996]. Parallel with the sample preparation, the same procedure is used to prepare a blank sample using the same quantities of all the reagents. Also two NIST SRMs are used to check the accuracy of the measurements.

\subsection{Homogeneity study}

The produced steel samples are divided into several groups. Each group is labeled prior to analyses. The samples are selected from all groups to ensure good sample representation. The selected samples are polished and quantitatively measured using XRF and OES to check the homogeneity of the prepared samples. Every sample is measured three times in order to check the within and between sample variability [ASTM international E572-02a]. The calibration of XRF is performed using NIST SRMs1765, 1766, 1767, 1761a, 1762a, 1261a and 1263a which were certified for carbon, aluminum, silicon, phosphorus, sulfur, titanium, vanadium, chromium, manganese, cobalt, nickel, cupper, arsenic and molybdenum. Two control samples are used to check the drift of XRF during measurements. One way-analysis of variance (ANOVA) is used to judge the homogeneity of the samples.

\section{Results and discussion}

Seven sets of low alloy steel were produced and quantitatively analyzed. They were labeled in the alphabetical order (A, B, C, D, F, K \& S). The chemical compositions (\%) of the produced alloys are shown in Table 1. 


\subsection{Traceability of measurements}

The traceability is achieved by using NIST SRMs for XRF, OES and AAS calibrations which are1765, 1766, 1767, 1761a, 1762a, 1261a, 361, 363,1261a, 1262a and 1263a.

\subsection{Homogeneity study}

The homogeneity study is designed so that the between sample variability and within sample variability can be studied [Adriaan M.H. -2000 and 2001]. The results obtained from the homogeneity study are analyzed by ANOVA (one-way layout). From these data, $\mathrm{F}_{\text {cal }} \mid \mathrm{F}_{\mathrm{tab}}$ for

Table1: Chemical compositions of the produced low alloy steel alloys

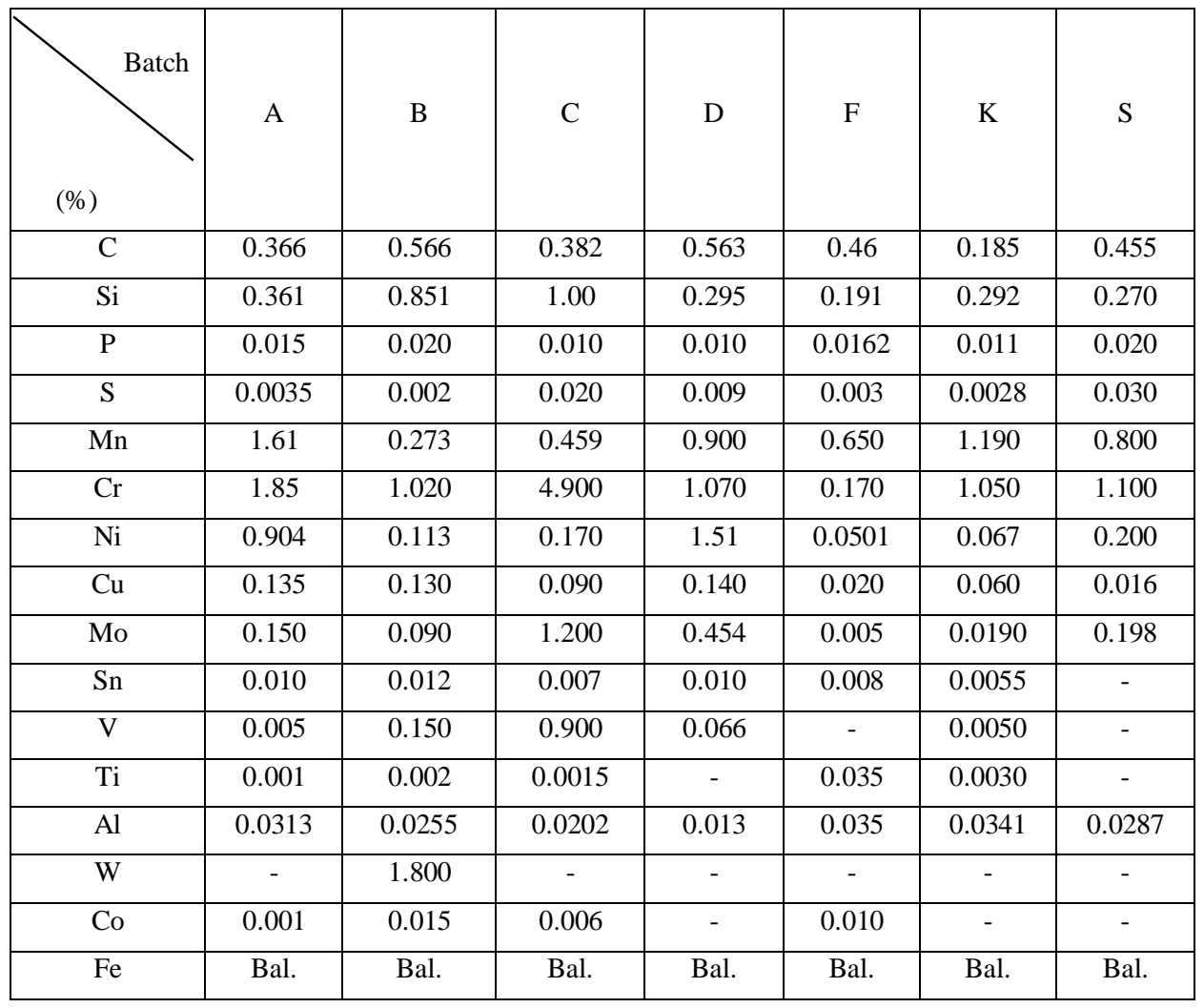

$\alpha(=5 \%)$ is small which means that the result of the homogeneity is insignificant. Thus, it can be concluded that the samples were homogenous. The uncertainty of the material homogeneity, $\sigma_{\mathrm{h}}{ }^{2}$, is also calculated from the ANOVA using equation (1).

$$
\sigma_{h}^{2}=\frac{M S_{B \text { etween }}-M S_{\text {Within }}}{n}
$$

Where, MS between is the mean square for the between sample variability, $\mathrm{MS}_{\text {within }}$ is mean square for the within sample variability and $\mathrm{n}$ is the three measurements taken for each of the 
6 samples. Values of P-values, $\mathrm{F}_{\text {cal }}, \mathrm{F}_{\text {Crit }}$ and $\sigma_{h}^{2}$ for batch $\mathrm{D}$ as an example are shown in

\section{Table 2.}

\subsection{Statistical treatment of the measurement results}

The results obtained are tested for normality, outliers, equality of means, and homogeneity of variances at 95\% confidence level [Fangmeyer H.- 1977, Costat statistical Software,

Minitab Inc., XLSTAT 7.5.2]. The tests indicate that the measurement results are normal after removing the outliers and the method variances are homogeneous expect those of the elements in batches shown in Table 3. 
Table 2: Homogeneity data of batch D

\begin{tabular}{|c|c|c|c|c|c|c|c|c|c|c|c|}
\hline Element & & D1-1 & D1-2 & D1-3 & D1-4 & D1-5 & D1-6 & $F_{\text {cal }}$ & $P$-value & $F_{c r i t}$ & $\sigma_{h}^{2}$ \\
\hline \multirow{3}{*}{ C } & R1 & 0.5350 & 0.5400 & 0.5500 & 0.5430 & 0.5480 & 0.5455 & \multirow{3}{*}{0.1697} & \multirow{3}{*}{0.9689} & \multirow{3}{*}{3.1059} & \multirow{3}{*}{0.0000117} \\
\hline & R2 & 0.5560 & 0.5410 & 0.5380 & 0.5500 & 0.5410 & 0.5380 & & & & \\
\hline & R3 & 0.5390 & 0.5460 & 0.5470 & 0.5470 & 0.5440 & 0.5529 & & & & \\
\hline \multirow{3}{*}{$\mathrm{Si}$} & R1 & 0.2880 & 0.2990 & 0.2920 & 0.2816 & 0.2830 & 0.2909 & \multirow{3}{*}{0.4247} & \multirow{3}{*}{0.8229} & \multirow{3}{*}{3.1059} & \multirow{3}{*}{0.000005} \\
\hline & R2 & 0.2970 & 0.2890 & 0.2900 & 0.2952 & 0.2890 & 0.2909 & & & & \\
\hline & R3 & 0.2810 & 0.2900 & 0.2950 & 0.2899 & 0.2920 & 0.2909 & & & & \\
\hline \multirow{3}{*}{$\mathbf{P}$} & R1 & 0.0094 & 0.0098 & 0.0095 & 0.0086 & 0.0103 & 0.0092 & \multirow{3}{*}{1.8435} & \multirow{3}{*}{0.1787} & \multirow{3}{*}{3.1059} & \multirow{3}{*}{0.0000001} \\
\hline & R2 & 0.0106 & 0.0096 & 0.0105 & 0.0099 & 0.0115 & 0.0095 & & & & \\
\hline & R3 & 0.0103 & 0.0100 & 0.0107 & 0.0095 & 0.0109 & 0.0110 & & & & \\
\hline \multirow{3}{*}{$\mathbf{S}$} & R1 & 0.0030 & 0.0041 & 0.0038 & 0.0033 & 0.0049 & 0.0020 & \multirow{3}{*}{0.272727} & \multirow{3}{*}{0.770255} & \multirow{3}{*}{5.143253} & \multirow{3}{*}{0.00000006} \\
\hline & R2 & 0.0042 & 0.0035 & 0.0031 & 0.0030 & 0.0048 & 0.0020 & & & & \\
\hline & R3 & 0.0043 & 0.0036 & 0.0037 & 0.0030 & 0.0049 & 0.0020 & & & & \\
\hline \multirow{3}{*}{ Mn } & R1 & 0.9100 & 0.8880 & 0.8980 & 0.9000 & 0.8940 & 0.8806 & \multirow{3}{*}{2.2756} & \multirow{3}{*}{0.1129} & & \\
\hline & R2 & 0.8806 & 0.8770 & 0.8572 & 0.8970 & 0.9180 & 0.9010 & & & 3.1059 & 0.00001 \\
\hline & R3 & 0.8696 & 0.8880 & 0.8572 & 0.9030 & 0.9140 & 0.9090 & & & & \\
\hline & R1 & 1.0700 & 1.1000 & 1.1100 & 1.0600 & 1.0797 & 1.0950 & & & & \\
\hline $\mathrm{Cr}$ & R2 & 1.1000 & 1.0900 & 1.0700 & 1.0700 & 1.1070 & 1.0940 & 1.8121 & 0.1849 & 3.1059 & 0.000005 \\
\hline & R3 & 1.1000 & 1.1100 & 1.0800 & 1.0600 & 1.0934 & 1.0540 & & & & \\
\hline & R1 & 0.0011 & 0.0015 & 0.0011 & 0.0012 & 0.0012 & - & & & & \\
\hline $\mathbf{T i}$ & R2 & 0.0012 & 0.0012 & 0.0014 & 0.0012 & 0.0012 & - & 3.1427 & 0.0646 & 3.4780 & 0.000000009 \\
\hline & R3 & 0.0010 & 0.0015 & 0.0012 & 0.0012 & 0.0012 & - & & & & \\
\hline & R1 & 1.4600 & 1.4500 & 1.4900 & 1.5100 & 1.5015 & 1.5012 & & & & \\
\hline $\mathrm{Ni}$ & R2 & 1.4700 & 1.4800 & 1.4900 & 1.5200 & 1.5036 & 1.5012 & 2.3130 & 0.1087 & 3.1059 & 0.000021 \\
\hline & R3 & 1.4900 & 1.4300 & 1.5100 & 1.4400 & 1.5026 & 1.5012 & & & & \\
\hline & R1 & 0.4630 & 0.4780 & 0.4610 & 0.4848 & 0.4730 & 0.4770 & & & & \\
\hline Mo & R2 & 0.4610 & 0.4750 & 0.4540 & 0.4528 & 0.4520 & 0.4830 & 2.5843 & 0.0826 & 3.1059 & 0.000056 \\
\hline & R3 & 0.4560 & 0.4560 & 0.4540 & 0.4554 & 0.4620 & 0.4900 & & & & \\
\hline & R1 & 0.0100 & 0.0090 & 0.0094 & 0.0081 & 0.0090 & - & & & & \\
\hline Sn & R2 & 0.0096 & 0.0100 & 0.0089 & 0.0095 & 0.0090 & - & 3.0332 & 0.0704 & 3.4780 & 0.00000015 \\
\hline & R3 & 0.0105 & 0.0098 & 0.0095 & 0.0090 & 0.0090 & - & & & & \\
\hline & R1 & 0.1410 & 0.1490 & 0.1390 & 0.1430 & 0.1420 & 0.1410 & & & & \\
\hline $\mathrm{Cu}$ & R2 & 0.1420 & 0.1400 & 0.1400 & 0.1440 & 0.1420 & 0.1400 & 1.7054 & 0.2078 & 3.1059 & 0.0000017 \\
\hline & R3 & 0.1390 & 0.1460 & 0.1390 & 0.1430 & 0.1420 & 0.1480 & & & & \\
\hline & R1 & 0.0152 & 0.0186 & 0.0168 & 0.0150 & 0.0148 & 0.0162 & & & & \\
\hline Co & R2 & 0.0172 & 0.0161 & 0.0178 & 0.0151 & 0.0150 & 0.0161 & 3.0830 & 0.0511 & 3.1059 & 0.00000059 \\
\hline & R3 & 0.0164 & 0.0157 & 0.0168 & 0.0150 & 0.0149 & 0.0142 & & & & \\
\hline & R1 & 0.0665 & 0.0691 & 0.0688 & 0.0603 & 0.0660 & 0.0672 & & & & \\
\hline V & R2 & 0.0679 & 0.0682 & 0.0649 & 0.0660 & 0.0640 & 0.0717 & 2.9123 & 0.0600 & 3.1059 & 0.0000006 \\
\hline & R3 & 0.0676 & 0.0688 & 0.0651 & 0.0670 & 0.0650 & 0.0694 & & & & \\
\hline
\end{tabular}


Where P-value, $\mathrm{F}_{\text {cal }}$ and $\mathrm{F}_{\text {Crit }}$ are statistical parameters. R1, R2 \& R3 are the measurement replicates respectively.

Table 3: Results which were not normal

\begin{tabular}{|c|c|}
\hline Element & Batch symbol \\
\hline $\mathrm{S}$ & $\mathrm{B}, \mathrm{F}$ \\
\hline $\mathrm{P}$ & $\mathrm{B}$ \\
\hline $\mathrm{Cu}$ & $\mathrm{F}$ \\
\hline $\mathrm{Mo}$ & $\mathrm{S}$ \\
\hline $\mathrm{Sn}$ & $\mathrm{A}, \mathrm{C}, \mathrm{F}, \mathrm{K}, \mathrm{S}$ \\
\hline $\mathrm{V}$ & $\mathrm{A}, \mathrm{K}, \mathrm{S}$ \\
\hline $\mathrm{Al}$ & $\mathrm{C}, \mathrm{F}, \mathrm{S}$ \\
\hline $\mathrm{Co}$ & \\
\hline
\end{tabular}

The mass fractions of these elements are reported as information values in the certification process.

\subsection{Assignment of reference value and its uncertainty}

Several methods in different laboratories are used for characterization of the elements in low alloy steel RMs. The average mass fraction of each element obtained by the methods is calculated. The steps involved in combining the available data to form a certified value and an uncertainty are: estimate the uncertainty of the method mean for each method used; estimate the between-method variance component and compute weights; compute the weighted mean and its variance; estimate and incorporate material variability; estimate the effective degrees of freedom for the combined variance; estimation of the bias allowance. [Schilier S.B- 1991 and 1996, Epstein M.S, 1991].

\section{Uncertainty of measurements of the mean of each method}

Since more than one analytical method are compared to determine the certified value, it is important that the variability of the mean for each method is estimated correctly [Adel B. S.2010, Eurachem/Citac guide CG 4-1993]. In order to estimate the standard uncertainty of the mean, two- way fully nested ANOVA was used to determine which design factors have a significant effect on the measurements. To calculate the type A uncertainty of each of the method means, equation (2) is used.

$$
\operatorname{Var}(y)=\frac{M S_{\text {Sample }}+M S_{\text {run }}-M S_{\text {error }}}{\text { Total Number of measurements }}
$$


Where $\operatorname{Var}(\mathrm{y})$ is type A uncertainty, $\mathrm{MS}$ sample is the sample mean square, $\mathrm{MS}_{\text {run }}$ is the run mean square and MS error is error mean square.

\section{Between method variance and method weights}

The measured values produced by each method are modeled as the sum of the true value $(\mathrm{m})$, method bias $\left(\mathrm{b}_{\mathrm{i}}\right)$ and random error $\left(\mathrm{e}_{\mathrm{ij}}\right)$ using equation (3).

$$
\text { The measured value }=m+b_{i}+e_{i j}
$$

Method weights are derived by assuming that the random errors $\left(\mathrm{e}_{\mathrm{ij}}\right)$ are independent, have mean 0 , and have different variance of each method $\left(\sigma_{i}^{2}\right)$. The variance $\sigma_{b}^{2}$ may be estimated from the between method difference. According to this model, the variance of the average of $\mathrm{n}_{\mathrm{i}}$ measurements from the $\mathrm{i}_{\mathrm{th}}$ method is:

$$
\frac{\sigma_{i}^{2}}{n_{i}}+\sigma_{b}^{2}
$$

To combine the averages of the analytical methods for each element, a weighted average of the method means was calculated according to the weighing algorithm of Paule and Mandel which is implemented for multi- method CRMs certification. The weight for each method, $\mathrm{W}_{\mathrm{i}}$ is inversely proportional to the sum of the combined standard uncertainty of the mean, $\mathrm{S}_{\mathrm{i}}{ }_{\mathrm{i}}$ and the between- method variance, $\sigma_{b}{ }^{2}$ The method weights $\left(\mathrm{W}_{\mathrm{i}}\right)$ are defined implicitly as follows:

$$
W_{i}=\frac{1}{s_{i}^{2}+\sigma_{b}^{2}}
$$

The weighing factor $\left(\mathrm{w}_{\mathrm{i}}\right)$ is given by:

$$
w_{i}=\frac{w_{i}}{\sum_{1}^{M} w_{j}}
$$

And $\tilde{X}$ the weighted average of the $\bar{X}$ s is calculated from:

$$
\tilde{X}=\sum_{1}^{M} w_{i} \overline{X_{i}}
$$

\section{The combined uncertainty}

The combined standard uncertainty of the weighted mean $(\tilde{X})$ is the weighted root sum of squares of the combined standard uncertainties for the methods according to:

$$
S^{2}=\sum_{1}^{M} \omega_{i}^{2} S_{i}^{2}
$$


This variance estimate $\left(S^{2}\right)$ does not include the between method variance. The variance of the mean summarizes random errors in the mean [Schilier S.B- 1991and 1996, Adel B. S.-2015]. It seems more realistic to include an allowance for bias or systematic error due to the difference in the methods. It is taken as the maximum absolute deviation of any method mean from the weighted mean:

$$
\text { Bias allowance }=\max \left|\widetilde{X}_{2}-\bar{X}\right|
$$

In order to estimate an appropriate interval for the certified value, the effective degree of freedom of the total variance is estimated according to SATTERTHWATTE formula which is:

$$
d f(\text { effective })=\frac{\left(\sum_{1}^{M \mu} \omega_{i}^{2} s_{i}^{2}+\sigma_{h 2}^{2}\right)}{\left(\sum_{1}^{M} \frac{\left(\omega_{i}^{2} s_{i}^{2}\right)^{2}}{n_{i}^{2}-1}+\frac{\sigma_{h}^{4}}{d f_{h}}\right)}
$$

Where, $\mathrm{df}_{\mathrm{h}}$ is the number of samples measured induplicate for material variability estimation minus one.

The total expanded uncertainty (U) associated with the certified values is according to:

$$
\mathrm{U}=t_{1-\alpha / 2} \sqrt{\left(S^{2}(\tilde{X})+\sigma_{h}^{2}\right)}+\text { Bias allowance }
$$

Where, $S^{2}(\tilde{X})$ is the weighted combined standard uncertainty and $\sigma_{h}^{2}$ is the uncertainty of the material heterogeneity.

The certified values and their associated expanded uncertainties are shown in Table 4. 
Table 4: The certified values and their associated expanded uncertainties for seven low alloy steel batches

\begin{tabular}{|c|c|c|c|c|c|c|c|c|}
\hline & & A & B & $\mathrm{C}$ & D & $\mathrm{F}$ & $\mathrm{K}$ & S \\
\hline \multirow[t]{2}{*}{$\mathrm{C}$} & $\begin{array}{c}\text { Certified } \\
\text { Value, }(\%)\end{array}$ & 0.3714 & 0.5708 & 0.3919 & 0.5508 & 0.4430 & 0.1858 & 0.4309 \\
\hline & $\mathrm{Uexp}(\%)$ & 0.0225 & 0.0443 & 0.0200 & 0.0352 & 0.0329 & 0.0136 & 0.0270 \\
\hline \multirow{2}{*}{$\mathrm{Si}$} & $\begin{array}{c}\text { Certified } \\
\text { Value, }(\%)\end{array}$ & 0.3546 & 0.8315 & 1.0072 & 0.2940 & 0.1893 & 0.2900 & 0.2734 \\
\hline & Uexp, $(\%)$ & 0.0291 & 0.0353 & 0.0324 & 0.0115 & 0.0119 & - & 0.0187 \\
\hline \multirow[t]{2}{*}{$\mathrm{P}$} & $\begin{array}{c}\text { Certified } \\
\text { Value, }(\%)\end{array}$ & 0.0158 & 0.02 & 0.0106 & 0.0101 & 0.0126 & 0.0114 & 0.0184 \\
\hline & $U \exp (\%)$ & 0.0027 & - & 0.0022 & 0.0020 & 0.0028 & 0.0025 & 0.0022 \\
\hline \multirow{2}{*}{ S } & $\begin{array}{c}\text { Certified } \\
\text { Value, }(\%)\end{array}$ & 0.0035 & 0.003 & 0.005 & 0.0027 & 0.003 & 0.0034 & 0.0324 \\
\hline & $\operatorname{Uexp}(\%)$ & 0.0004 & - & & 0.0010 & - & 0.0010 & 0.0075 \\
\hline \multirow[t]{2}{*}{$\mathrm{Mn}$} & $\begin{array}{c}\text { Certified } \\
\text { Value, }(\%)\end{array}$ & 1.6156 & 0.2768 & 0.4735 & 0.8572 & 0.6148 & 1.2115 & 0.8282 \\
\hline & $\operatorname{Uexp}(\%)$ & 0.0282 & 0.0203 & 0.0205 & 0.0334 & 0.0396 & 0.0604 & 0.0239 \\
\hline \multirow{2}{*}{$\mathrm{Cr}$} & $\begin{array}{c}\text { Certified } \\
\text { Value, }(\%)\end{array}$ & 1.8975 & 1.0381 & 4.8832 & 1.0681 & 0.1744 & 1.0744 & 1.0931 \\
\hline & $\operatorname{Uexp}(\%)$ & 0.0313 & 0.0211 & 0.0580 & 0.0326 & 0.0181 & 0.0374 & 0.0682 \\
\hline \multirow[t]{2}{*}{$\mathrm{Ni}$} & $\begin{array}{c}\text { Certified } \\
\text { Value, }(\%)\end{array}$ & 0.9512 & 0.1148 & 0.1640 & 1.5107 & 0.0514 & 0.0672 & 0.2150 \\
\hline & $\operatorname{Uexp}(\%)$ & 0.0181 & 0.0114 & 0.0033 & 0.0515 & 0.0044 & 0.0038 & 0.0114 \\
\hline \multirow{2}{*}{$\mathrm{Cu}$} & $\begin{array}{c}\text { Certified } \\
\text { Value, }(\%)\end{array}$ & 0.1348 & 0.1287 & 0.0843 & 0.1430 & 0.0218 & 0.0603 & 0.016 \\
\hline & $\mathrm{Uexp}(\%)$ & 0.0136 & 0.0074 & 0.0062 & 0.0074 & 0.0048 & 0.0040 & - \\
\hline \multirow[t]{2}{*}{ Mo } & $\begin{array}{c}\text { Certified } \\
\text { Value, }(\%)\end{array}$ & 0.1449 & 0.0903 & 1.2085 & 0.4786 & 0.005 & 0.0197 & 0.2131 \\
\hline & $\mathrm{Uexp}(\%)$ & 0.0091 & 0.0055 & 0.0329 & 0.0428 & - & 0.0015 & 0.0099 \\
\hline \multirow[t]{2}{*}{ Sn } & $\begin{array}{c}\text { Certified } \\
\text { Value, }(\%)\end{array}$ & 0.0106 & 0.0123 & 0.0070 & 0.0094 & 0.0070 & 0.0106 & - \\
\hline & $\mathrm{Uexp}(\%)$ & 0.0029 & 0.0033 & 0.0019 & 0.0026 & 0.0019 & 0.0029 & - \\
\hline \multirow[t]{2}{*}{$\mathrm{V}$} & $\begin{array}{c}\text { Certified } \\
\text { Value, }(\%)\end{array}$ & 0.005 & 0.1534 & 0.900 & 0.0671 & 0.003 & 0.005 & 0.002 \\
\hline & $\operatorname{Uexp}(\%)$ & - & 0.0039 & - & 0.0064 & - & - & - \\
\hline \multirow[t]{2}{*}{$\mathrm{Ti}$} & $\begin{array}{c}\text { Certified } \\
\text { Value, }(\%)\end{array}$ & 0.001 & 0.0017 & 0.002 & 0.0013 & 0.001 & 0.003 & 0.001 \\
\hline & $\mathrm{Uexp}(\%)$ & - & 0.0009 & - & - & - & - & - \\
\hline \multirow[t]{2}{*}{$\mathrm{Al}$} & $\begin{array}{c}\text { Certified } \\
\text { Value, }(\%)\end{array}$ & 0.031 & 0.0136 & 0.0198 & 0.0142 & 0.0349 & 0.033 & 0.025 \\
\hline & $\mathrm{Uexp}(\%)$ & - & 0.0007 & 0.0028 & 0.0022 & 0.0021 & - & - \\
\hline \multirow[t]{2}{*}{$\mathrm{Co}$} & $\begin{array}{c}\text { Certified } \\
\text { Value, }(\%)\end{array}$ & 0.01225 & 0.01608 & 0.01 & 0.0155 & 0.010 & 0.0122 & 0.004 \\
\hline & $\operatorname{Uexp}(\%)$ & 0.0025 & 0.0004 & - & 0.0037 & - & 0.0025 & - \\
\hline \multirow{2}{*}{ W } & $\begin{array}{l}\text { Reference } \\
\text { Vaue, }(\%)\end{array}$ & 0.015 & 1.8428 & 0.015 & 0.015 & 0.012 & 0.001 & 0.0012 \\
\hline & $\operatorname{Uexp}(\%)$ & - & 0.097 & - & - & - & - & - \\
\hline
\end{tabular}


Values edited in bold are information values since they did not pass the test for normality of data and the between method variance was very large as well. In addition there was a large difference between the means of the analytical methods used for analysis. Therefore, it was not possible to estimate the associated uncertainties in clear traceability to the SI units.

\section{Conclusion}

Low alloy steel reference materials were manufactured and certified for the mass fraction content of carbon, silicon, manganese, phosphorus, sulfur, chromium, nickel, copper, molybdenum, vanadium, tungsten, aluminum, cobalt and niobium using six independent analytical methods in four different laboratories. Certification was carried out in full compliance with ISO Guide 35 and measurement results were statistically treated for normality, outliers, equality of means and variances. The certification process revealed that certified values have been obtained for most of the elements except for $\mathrm{V}$, Ti and $\mathrm{W}$, where information values were obtained except in one batch for each element. The produced certified reference materials provide a basis for further improvement in quality of low alloy steel analysis and production.

\section{References}

Adel B. S., Ibrahim F. T.," Preparation and certification of a fish oil natural matrix reference material for organochlorine pesticides" J. Accred Qual Assur, vol. 15, pp. 563-568 (2010). Adel B. S., Mahmoud S. R., Ahmed M. F., Ibrahim F. T.,"Development of two reference materials for all trans-retinol, retinyl palmitate, $\alpha$ - and $\gamma$ - tocopherol in milk powder and infant formula" J. Food and Drug Analysis, vol. 23, pp. $82-92$ (2015)

Adriaan M.H., van der Veen Jean Pauwels, "Uncertainty calculations in the certification of reference materials. 2. Homogeneity study" J. Accred Qual Assur, vol. 6, pp. 26-30 (2001). Adriaan M.H. van der Veen Jean Pauwels,"Uncertainty calculations in the certification of reference materials. 1. Principles of analysis of variance" J. Accred Qual Assur, vol. 5, pp.464-469 (2000).

Amigo J.M., Arana G, Etxebairria N, and Fernandez LA, "Emerging needs for sustained production of laboratory reference materials" J. Trends Anal Chem, vol. 23, pp 80-85 (2004). 
Al-Eshaikh M. A. and Kadachi A.,"Elemental analysis of steel products using X-ray fluorescence (XRF) technique" J. King Saud University- Engineering Sciences, vol. 23, pp.75-79 (2011).

ASTM international E572-02a "Standard test method for analysis of stainless and alloy steel by X-ray fluorescence spectrometry" (2002)

Charles S. D., Statistical Methods for the Analysis of Repeated Measurements, Springer, ISBN 0-387-95370-1 San Diego, USA, 2002

Costat statistical Software (CoHort Software, Pacific Grove, CA, U.S.A.)

Emons H, TPJ L., and B.M Gawlik, "Reference materials: terminology and use" J. Trends Anal. Chem., vol 23, pp 442-449 (2004).

Epstein M.S, "The independent method concept for certifying chemical composition reference materials", J. Spectrochimica Acta, vol.468 (1991).

Eurachem/Citac guide CG 4 "Quantifying uncertainty in analytical measurement", 2nd Edn Guide to the Expression of Uncertainty in Measurements, International Organization of Standardization (ISO), Geneva, 1993

Fangmeyer H., Haemers L., Larisse J., "Statistical approach for collaborative tests reference material certification procedures", Joint Research Centre Ispra Establishment Italy, (1977).

ISO-Guide 35 "Certification of reference materials - General and statistical principles", (1992).

Hoffmann P., Jihrling R. , Minh Tu N. T., Bowitz R., Kiibler A., Hein M., Stinglt U., and Lieser K. H.," Examination of steel samples, provided as reference materials by instrumental analysis" J. Fresenius J Anal. Chem., 342: 312- 317 (1992)

Minitab Inc. Brandon Court, Progress Way, Coventry, UK

PerkinElmer publication, "Analytical Methods for Atomic Absorption Spectroscopy"

Perkin-Elmer Corporation, USA, 1996

PerkinElmer publication, "Reference Notebook of Microwave Applications" Perkin-Elmer Corporation, 1996 
Schilier S.B., " Standard Reference Materials: Statistical Aspects of the Certification of Chemical Batch SRMs" NIST special publication 260-125 (1996).

Schilier S.B. and Eberhadt K.R., "Combining data from independent chemical analysis methods" J. SpectrochimicaActa, vol. 46B, pp. 1607-1613 (1991).

XLSTAT 7.5.2 (Addinsoft, New York, U.S.A.) 


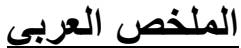

\section{تحضير و توصيف بعض انواع المواد المرجعية من سبائك الصلب}

عادل بسيونى السيد شحاته1, , عصام عبد العزيز كيشار², دعاء عبد المنعم أحمد².. راندا نصر أحمد1

$$
\text { 1. - المعهد القومى للقياس و المعايرة- الهرم- الجيزه }
$$

2. قسم الكيمياء- كلية البنات للآداب و العلوم و التربية- جامعة عين شمس- القاهره

تلعب المو اد المرجعية المعتمدة دورا هاما في التحقق من دقة نتائج القياسات التحليلية. وهي تستخدم فى الاغراض الاتيه:

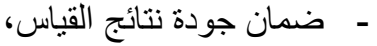

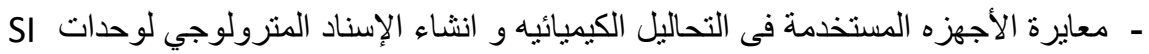
- تقدير اللايقين فى نتائج القياس وبذلك يمكن عمل مقارنات مع نتائج أخرى أو المر اجع أو المو اصفات أونات أو المعايير.

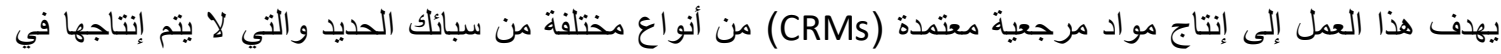

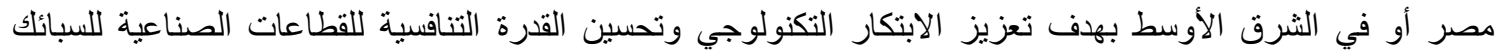

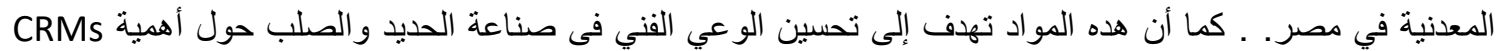

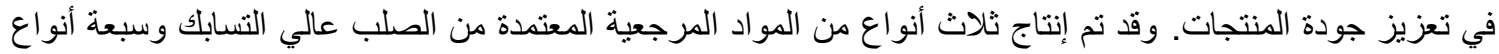

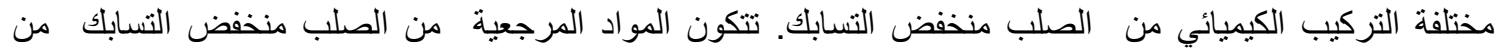

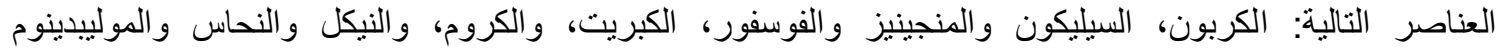

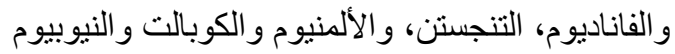

تكنولوجيا التصنيع

تم إنتاج السبائك المختلفة فى معهد بحوث وتطوير الفلزات (CMRDI) باستخدام فرن الحث الكهربي ذي البوتقة الثابتة سعة 100 كجم. تبدأ عملية تصنيع سبائك الصلب المنخفض التسابك بصهر الصلب الكربوني ثم إضافة باقى العناصر

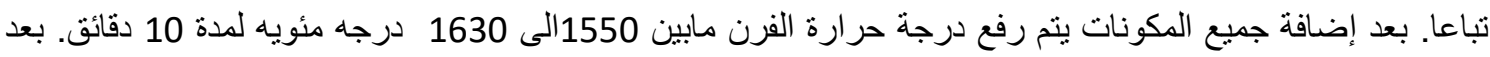

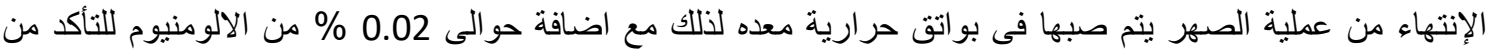

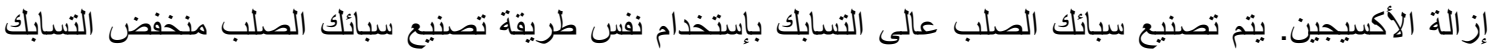
بإستخدام خردة الصلب الكربوني عند درجات حر ارة 1620-1630 درجة مئوية.

تم إختبار العينات المنتجة للتأكد من درجة التجانس بإستخدام جهاز التحليل بالأشعة السينية الفلورنسية، و كذلك بإنتخدام مطياف الأنبعاث الضوئي و تحليل البيانات إحصائيا باستخدام تحليل التباين الأحادي (ANOVA). وقد وجد أنيات أن المواد

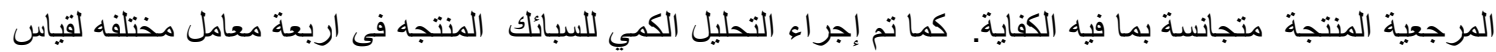
نسب العناصر المختلفه فى كل سبيكة باستخدام جهاز التحليل بالأشتعة السينية الفلورنسية وجهاز مطياف الإنبعاث الضوائي التئي و جهاز الإمتصاص الذري وطرق الجر افيمتري. و قد تم إختبار خمسة عينات عشو ائيا لإجر اء الاختبار ات المخدة المختلفة.

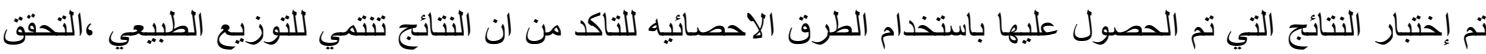

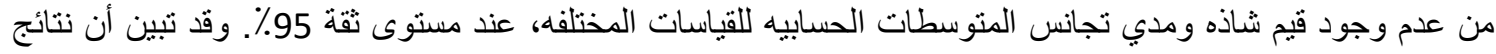
القياس تنتمي الى التوزيع الطبيعي بعد إز الة القيم الثناذه، وأن المتوسطات الحسابه الحسابيه متجانسه.

وقد نم الجمع بين جميع نتائج القياس و التي نم الحصول عليها عن طريق أجهزة مختلفة من معامل مختلفة عن طريق

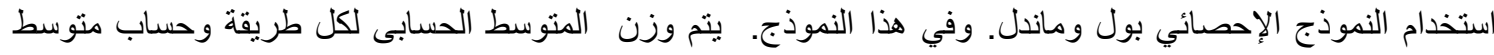


المتوسطات الموزونه (القيمة المرجعيه). كما يتم تقدير اللايقين الموزون المصاحب لمتوسط المتوسطات الموزونه وتم تقدير ها من ثناثة مصادرو هي:

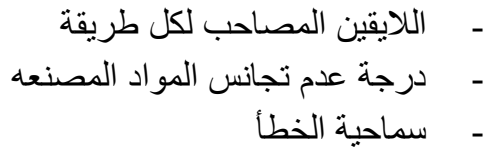

تعتبرعملية تصنيع وتوصيف المواد المرجعيه من سبائك الصلب هي الاولى فى مصر . . وهي تستخدم فى عمليات المعايرة ولتوكيد جودة المنتجات من الصلب منخفض التسابك والصلب عالى التسابك وضمان إنتاجها طبقا للمواصفات الفنية المطلوبة. 